\title{
Two Resistance Modes to Clover yellow vein virus in Pea Characterized by a Green Fluorescent Protein-Tagged Virus
}

\author{
Marcelo Andrade, Masanao Sato, and Ichiro Uyeda
}

Pathogen-Plant Interactions Group, Graduate School of Agriculture, Hokkaido University, Sapporo, Japan 060-8589. Accepted for publication 14 November 2006.

\begin{abstract}
Andrade, M., Sato, M., and Uyeda, I. 2007. Two resistance modes to Clover yellow vein virus in pea characterized by a green fluorescent protein-tagged virus. Phytopathology 97:544-550.

This study characterized resistance in pea lines PI 347295 and PI 378159 to Clover yellow vein virus (ClYVV). Genetic cross experiments showed that a single recessive gene controls resistance in both lines. Conventional mechanical inoculation did not result in infection; however, particle bombardment with infectious plasmid or mechanical inoculation with concentrated viral inocula did cause infection. When CIYVV No. 30 isolate was tagged with a green fluorescent protein (GFP) and used to monitor infection, viral cell-to-cell movement differed in the two pea lines. In PI 347595, ClYVV replicated at a single-cell level, but did not
\end{abstract}

ABSTRACT move to neighboring cells, indicating that resistance operated at a cell-tocell step. In PI 378159, the virus moved to cells around the infection site and reached the leaf veins, but viral movement was slower than that in the susceptible line. The viruses observed around the infection sites and in the veins were then recovered and inoculated again by a conventional mechanical inoculation method onto PI 378159 demonstrating that ClYVV probably had mutated and newly emerged mutant viruses can move to neighboring cells and systemically infect the plants. Tagging the virus with GFP was an efficient tool for characterizing resistance modes. Implications of the two resistance modes are discussed.

Additional keyword: potyvirus.
Resistance to potyviruses operates at any step of the viral multiplication cycle, and in many cases, is characterized by recessive resistance genes. For example, the recessive gene $y^{a}$ confers resistance to some isolates of Potato virus $Y$ (PVY) by blocking cell-to-cell movement (1). Deom et al. (5) noted that the recessive gene $e t^{a}$ in pepper plants confers resistance to Tobacco etch virus (highly aphid-transmissible) by interfering with virus production. The sbml resistance gene to Pea seedborne mosaic virus pathotype 1 in pea operates at a single-cell level, probably by blocking virus replication (12). The $v a$ gene resists PVY and restricts its cell-to-cell movement in tobacco plants (14). In potato, the $r a$ gene blocks the vascular transport of Potato virus A (PVA) by graft inoculation (9).

Some recessive resistant genes to potyviruses in pea have already been identified, including mo that confers resistance to Bean yellow mosaic virus (BYMV) and Watermelon mosaic virus-2 (23), bcm that confers resistance to Bean common mosaic virus (17), $p w v$ that confers resistance to Passionfruit woodiness virus (19), and wlv that confers resistance to White lupin mosaic virus (18). Further, the sbml (12), sbm2, and sbm4 (10) genes confer resistance to Pea seed-borne mosaic virus. Two recessive resistant genes, $c y v$ and $c y v-2$, conferring resistance to Clover yellow vein virus (ClYVV) have also been reported (16).

Dominant or semidominant genes have also been reported to resist infection by potyviruses. Dominant resistance genes, such as TuRBO1 and TuRBO2, have been found to confer resistance to Turnip mosaic virus (TuMV) in Brassica crops. The resistance mechanisms of TuRBO1 are not well understood; however, TuMV can multiply on inoculated leaves of Brassica napus without developing a hypersensitive response (HR) (31). Collmer et al. (4) reported that the $I$ gene, which confers resistance to Bean

Corresponding author: I. Uyeda; E-mail address: uyeda@res.agr.hokudai.ac.jp

doi:10.1094/PHYTO-97-5-0544

(C) 2007 The American Phytopathological Society common mosaic virus in common bean (Phaseolus vulgaris), is not a dominant gene, but rather, is an incompletely dominant and dosage-dependent allele that develops a response varying from extreme resistance to HR or vascular necrosis. Dominant viral resistance genes in potato have been described worldwide, with a large number of alleles providing resistance to various strains of PVY and PVA, and host responses ranging from extreme resistance to HR (24).

CIYVV belongs to the genus Potyvirus and is closely related to BYMV (30). Takahashi (27) constructed a highly infectious plasmid of CIYVV isolate No. 30 cDNA using a Cauliflower mosaic virus (CaMV) $35 \mathrm{~S}$ promoter. Green fluorescent protein (GFP) cDNA was inserted between the P1 and helper componentproteinase (HC-Pro) regions of the ClYVV genome (15) to monitor viral replication and movement in plants. This infectious cDNA construct has allowed characterization of resistance mechanisms in legume plants. For example, Sato et al. (22) reported a single recessive gene called desc in Jolanda (a common bean line). Because no GFP fluorescence was observed at the singlecell level when the infectious cDNA of GFP-tagged CIYVV was particle bombarded in Jolanda, desc probably operated to inhibit the translation or replication of the viral RNA.

Here, we characterize resistance to CIYVV in pea plants using GFP-tagged virus. Based on the viral movement in plants, we found two different resistance modes in pea.

\section{MATERIALS AND METHODS}

Plant material, viruses, and plasmids. Pea lines (Pisum sativum) were obtained from C. Coyne, U.S. Department of Agriculture-Agricultural Research Service (USDA-ARS), Western Regional Plant Introduction Station, Washington State University. ClYVV/C3-S65T is isolate No. 30 of the CIYVV carrying the GFP cycle 3 mutant recovered from a single bacterial colony harboring plasmid pClYVV/C3-S65T as described by Sato et al. (22). ClYVV-Br is a mutant virus that breaks the resistance to 
ClYVV in common bean cv. Jolanda and has been described by Sato et al. (22). The CS strain of BYMV was isolated from red clover in Hokkaido, Japan, and identified as BYMV based on the nucleotide sequence of the coat protein gene and serology (21, 28). pE2113-ECFP carries cyan fluorescent protein (CFP) under the enhanced CaMV 35S promoter (22). ClYVV-Pst1/CP is also a No. 30 isolate of ClYVV, but has no insertion of GFP (15).

Selection of resistant pea lines. In preliminary experiments, 202 pea lines were screened by mechanical inoculation with CIYVV-Pst1/CP (15) followed by observation of symptom development (20). Lines that showed no symptoms were selected as candidates for resistance (data not shown). About 31 selected pea lines were grown in chamber conditions $\left(23^{\circ} \mathrm{C}\right.$ for $18 \mathrm{~h}$ under fluorescent lights) and mechanically inoculated with ClYVV/C3S65T. Then, infection was identified by GFP detection and indirect enzyme-linked immunosorbent assay (ELISA) from upper noninoculated leaves.

GFP and enhanced CFP detection. An epifluorescence microscope (SZX-12; Olympus, Tokyo) equipped with a filter cube (SZX-MGFPA; Olympus; GFP and CFP filters) was used to detect GFP and enhanced CFP (ECFP) fluorescence. Pictures were recorded with a charge-coupled device camera (VB-6010; Keycence, Osaka, Japan).

Indirect ELISA. Sample leaves were macerated in phosphatebuffered saline (PBS)-Tween $20(10 \mathrm{ml} / \mu \mathrm{l})(0.01 \mathrm{M}$ phosphate buffer, pH 7.0, with $0.05 \%$ Tween 20). The wells were coated with anti-ClYVV immunoglobulin $\mathrm{G}$ (from mouse) diluted $1: 10,000$ in $200 \mu \mathrm{l}$ of $0.05 \mathrm{M}$ sodium carbonate ( $\mathrm{pH}$ 9.6) and incubated at $37^{\circ} \mathrm{C}$ for $2 \mathrm{~h}$. After washing, $200 \mu \mathrm{l}$ of sap was added and incubated at $4{ }^{\circ} \mathrm{C}$ overnight. A second rabbit-derived antibody was added at a concentration of $1 \mu \mathrm{g} / \mu \mathrm{l}$ in $200 \mu \mathrm{l}$ of PBS-Tween 20 and incubated at $37^{\circ} \mathrm{C}$ for $4 \mathrm{~h}$. Alkaline phosphatase conjugated goat anti-rabbit was added (Zymed Laboratories, San Francisco, CA) at a dilution of 1:10,000 in $200 \mu \mathrm{l}$ of PBS-Tween 20 and incubated at $37^{\circ} \mathrm{C}$ for $4 \mathrm{~h}$. After addition of $200 \mu \mathrm{l}$ of substrate solution $(0.001 \mathrm{~g}$ of disodium $\rho$-nitrophenyl-phosphate hexahydrate in $1 \mathrm{ml}$ of diethanolamine), ELISA values were read after 15 to 30 min with optical density at $405 \mathrm{~nm}$.

Biolistic assay. To coat tungsten particles, approximately $1 \mu \mathrm{g}$ of both pClYVV/C3-S65T and pE2113-ECFP (22) was mixed together into $30 \mu \mathrm{l}$ of tungsten solution $(50 \mathrm{mg} / \mathrm{ml}$ of Tungsten M20 P.N.75055, Bio-Rad Laboratories, Hercules, CA), $30 \mu \mathrm{l}$ of $1.25 \mathrm{M}$ calcium nitrate ( $\mathrm{pH} 10.5)$, and distilled water to a final volume of $100 \mu \mathrm{l}$. Approximately $250 \mu \mathrm{l}$ of ethanol was added and then sedimented and suspended in $60 \mu \mathrm{l}$ of ethanol (6). Particle bombardment was performed with a PDS-1000/He Particle Delivery System (Bio-Rad Laboratories) on three detached leaves from three different individuals of each line at the four-leaf stage. In addition, four individual plants of PI 378159 were particle bombarded with pCIYVV/C3-S65T by particle gun developed by Gal-On et al. (6).

Production of highly infectious CIYVV/C3-S65T inocula. ClYVV/C3-S65T propagated in broad bean (Vicia faba) was macerated in tissue $(5 \mathrm{ml} / \mathrm{g})$ in an extraction buffer $(0.1 \mathrm{M}$ Tris, $\mathrm{pH} 7.5,0.05 \mathrm{M}$ EDTA, and $1 \%$ mercaptoethanol) followed by the addition of $5 \%$ Triton $\mathrm{X}-100$. The extract was treated by adding $20 \%$ total volume of chloroform. The aqueous phase was centrifuged at $65,000 \times g$ for $90 \mathrm{~min}$, and the pellet was suspended in Tris buffer (0.01 M Tris, $\mathrm{pH} 7.5)$. The pellet from each $10 \mathrm{~g}$ of macerated tissue was concentrated in $1 \mathrm{ml}$ of Tris buffer.

The concentration of the concentrated viral inoculum was determined by indirect ELISA and compared with the inoculum used for conventional mechanical inoculation $(0.1 \mathrm{~g}$ of tissue macerated in $1 \mathrm{ml}$ of $0.01 \mathrm{M}$ Tris, $\mathrm{pH} 7.0$, and $1 \%$ mercaptoethanol). For that purpose, ClYVV/C3-S65T was purified as in Uyeda et al. (29) and suspended in $0.01 \mathrm{M}$ phosphate buffer $(\mathrm{pH}$ 7.0). The viral concentration was estimated spectrophotometrically to be $280 \mathrm{mg} / \mathrm{ml}$. This purified virus was used as a standard during the indirect ELISA procedure. The inoculum for conventional mechanical inoculation was obtained at a concentration of $6 \mu \mathrm{g} / \mathrm{ml}$, and concentrated viral inoculum was obtained at a concentration of $1.5 \mathrm{mg} / \mathrm{ml}$. And serial $\times 10$ fold dilutions (150, 15 , and $1.5 \mu \mathrm{l} / \mathrm{ml}$ ) were made from the concentrated viral inoculum.

Infectivity assay. In the resistant line PI 378159 and susceptible line Mametaro, three to four individuals were mechanically inoculated with the inocula for conventional mechanical inoculation and with concentrated viral inocula. For all plants, the inoculated leaf was scored by the absence or presence of GFP, as well as the number of infection sites. Plant infection was determined by GFP detection and the reverse transcription-polymerase chain reaction (RT-PCR) of total RNA from the upper noninoculated leaves.

RT-PCR. Approximately $0.1 \mathrm{~g}$ of the youngest and most apical leaves was macerated in the extraction buffer (0.1 M Tris, $\mathrm{pH} 7.5$, $0.05 \mathrm{M}$ EDTA, and $1 \%$ mercaptoethanol). This extract was then treated by adding $20 \%$ the total volume of chloroform followed by centrifugation. Into the aqueous phase, $20 \%$ polyethylene glycol-2.5 M NaCl was added for a final solution of $4 \%$; this solution was centrifuged, and the precipitates were suspended in $100 \mu \mathrm{l}$ of Tris-EDTA ( $\mathrm{pH}$ 8.0). Then, $500 \mu \mathrm{l}$ of TRIzol (Invitrogen, Carlsbad, CA) was added, centrifuged, and the supernatant was treated with chloroform/isoamyl alcohol. Total RNA was precipitated in ethanol and suspended in distilled water. The cDNA was synthesized using cloned Avian myeloblastosis virus Reverse Transcriptase (Invitrogen) with an oligo dT primer (Takara Bio, Inc., Otsu, Japan) following the manufacturer's specifications. The DNA was used as a template for PCR to amplify a 500-bp fragment within the coat protein using the primer pair $5^{\prime}$ AATGTTGGTGAGCAACAA-3' and 5'-CATACCCGACGTCTCTTTAG- $3^{\prime}$ at the following conditions: $94^{\circ} \mathrm{C}$ for $5 \mathrm{~min}, 30$ cycles of $94^{\circ} \mathrm{C}$ for $30 \mathrm{~s}, 60^{\circ} \mathrm{C}$ for $30 \mathrm{~s}, 72^{\circ} \mathrm{C}$ for $1 \mathrm{~min}$, and finally, $72^{\circ} \mathrm{C}$ for $5 \mathrm{~min}$. The RT-PCR procedure was carried out in two independent experiments at 21 and 40 days after inoculation (dai).

Inoculation on detached leaves. To preserve the F1 plants to obtain progeny seeds, two leaves were cut out and used for the inoculation test. Mechanically inoculated leaves were kept under chamber conditions in a petri dish with a moisture filter paper. The GFP fluorescence was monitored from 3 to 7 dai.

Cleaved amplified polymorphic sequence assay. To confirm successful crossing between susceptible and resistant lines, the isolated genomic DNA from parental and crossed lines was isolated using DNAzol reagent (Invitrogen) and subjected to cleaved amplified polymorphic sequence (CAPS) assay. The primer pair 5' -CTGGTTGGTCCTTCCTTATTTTAC-3' and 5' -AACGGATAAAGAGTGACAAGAACC-3' (8) amplified a fragment of approximately $500 \mathrm{bp}$. The amplified DNA was further restricted with the restriction enzyme $A f a \mathrm{I}$. Polymorphism was assayed using agarose gel electrophoresis.

\section{RESULTS}

Identification of resistance to CIYVV in pea. A total of 202 lines randomly selected from the USDA-ARS germ plasm resources information network were mechanically inoculated, and symptom development was observed for about 2 weeks. Lines that showed no symptoms were selected, and further inoculation tests were conducted. Resistance to CIYVV was found in 31 lines. These lines were then screened for systemic infection by mechanical inoculation using GFP-tagged virus. The following 28 pea lines showed resistance to ClYVV/C3-S65T: PI 116843, PI 162909, PI 163125, PI 163129, PI 164548, PI 169603, PI 184131, PI 269810, PI 269816, PI 272175, PI 272194, PI 340130, PI 347295, PI 347477, PI 356973, PI 356974, PI 356080, PI 356986, PI 356991, PI 356992, PI 357292, PI 378158, PI 378159, PI 429853, PI 476410, PI 505111, W6-15451, and W6-15452. GFP 
fluorescence was detected on the inoculated leaves of susceptible lines, such as Mametaro and PI 250438, approximately 3 to 4 dai and on the upper leaves approximately 7 to 10 dai. At 14 dai, ELISA was conducted on the upper noninoculated leaves of all lines to examine ClYVV infection. No viral infection was detected by ELISA.

Progeny analysis of crosses between resistant and susceptible lines. The susceptible pea line PI 250438 used as a male parent was crossed with six resistant lines (PI 162909, PI 347295, PI 356986, PI 378158, PI 378159, and PI 459853). The crossing experiments showed that all F1 plants were susceptible to viral infection, indicating a recessive resistance to ClYVV/C3-S65T in those lines (Table 1). The CAPS assay indicated that all plants were successfully crossed. PI 347295 and PI 378159, representing each of the two resistance modes and described in the next section, were chosen for further genetic experiments. Susceptibility was determined by ELISA of noninoculated leaves. Susceptible and resistant plants were segregated at 3:1, respectively, in F2 progenies, indicating that a single recessive gene governs resistance to ClYVV (Table 2).

To verify whether the results of inoculation on detached leaf agree with the results of the inoculation on entire plant, 20 out of 100 F2-population plants were randomly selected. Leaves were detached and inoculated with ClYVV/C3-S65T. At the same time, the plants were also mechanically inoculated with ClYVV/C3S65T. In PI 347295 and PI 378159, inoculation of the detached leaf and the whole plant agreed perfectly with the results on entire plant. For the next experiments, all plants used were parental individuals from original stock donated by the USDA-ARS.

Characterization of resistance using GFP-tagged CIYVV. Sato et al. (22) reported that recessive resistance in Jolanda bean was caused by inhibition of the viral replication step. Using particle bombardment of pClYVV/C3-S65T, which carries GFP, we found no GFP fluorescence at the single-cell level. To determine whether the resistance mode in pea is similar to that in Jolanda bean, a particle bombardment experiment was conducted.

For this experiment, pClYVV/C3-S65T and p2113-ECFP (control) were mixed together and coated to tungsten particles, and then particle bombarded to detached leaves of parental resistant pea lines. In lines PI 162909, PI 347295, and PI 429853 at 1 dai, fluorescence was detected under the GFP and ECFP filters at the single-cell level; however, no movement to other cells occurred, even at 9 dai. In contrast, at approximately 3 dai, GFP fluorescence spread to neighboring cells in PI 356986, PI 378158, and PI 378159 and reached the leaf veins at 7 dai (Fig. 1). The number of infected sites varied from 50 to 60 per leaf and did not differ among the pea lines (data not shown).

To determine whether ClYVV can replicate in PI 347295 or whether observed fluorescence was caused by translation of viral RNA driven by the CaMV 35S promoter, concentrated viral inocula derived from pClYVV/C3-S65T were mechanically inoculated on detached leaves of PI 347295, PI 378159, and Mametaro. In PI 347295, GFP fluorescence was detected at the single-cell level at 3 dai; however, GFP fluorescence never spread to surrounding cells, even at 9 dai. Thus, we concluded that CIYVV/C3-S65T can replicate only at a single-cell level. In PI 378159 , GFP fluorescence was observed at 3 dai; fluorescence subsequently spread to neighboring cells, reaching the veins at 10 dai. In Mametaro, the results were very similar to the particle bombardment assay (Fig. 2). When the same concentrated viral inocula were used to inoculate PI 378159, four out of five inoculated plants showed GFP fluorescence on noninoculated leaves (data not shown). This indicates that PI 378159 could be infected when concentrated viral inocula were used or mutant viruses could appear if the plant is infected with CIYVV/C3-S65T. In order to test whether viruses in the systemically infected leaves of PI 378159 is the mutant virus or not, PI 378159 plants were inoculated with concentrated viral inocula. Three individuals were systemically infected with those inocula (Table 3). Two individuals became infected when the most concentrated inoculum was used $(1.5 \mathrm{mg} / \mathrm{ml})$, as determined by presence of GFP fluorescence on inoculated leaves at 4 dai and on the upper leaves at 19 dai. In another individual inoculated with inoculum $(150 \mathrm{mg} / \mathrm{ml})$, GFP was detected on upper leaves very late at 33 dai. In contrast, in the susceptible line Mametaro, in all concentrations, GFP fluorescence was detected on inoculated leaves at 2 dai and on upper leaves at 5 dai. The viruses present on the systemically infected leaves of PI 378159 were recovered and then their crude extracts were directly used for conventional mechanical inoculation on PI 378159. In all three, recovered viruses could infect systemically. Because the wild-type virus cannot infect PI 378159 by conventional mechanical inoculation, it was suggested that they are mutants that can break the resistance in PI 378159.

Analysis of the virus movement in PI 378159. Four individuals of PI 378159 were particle bombarded with pClYVV/C3S65T by a particle gun. In three individuals, GFP development on the inoculated leaves occurred as expected, spreading cell-to-cell and reaching the veins. Unexpectedly, GFP spread toward the upper noninoculated leaves around 12 dai. To examine whether viruses present in systemically infected leaves are a wild type or mutants, the leaves showing GFP fluorescence from individual plants were used for mechanical inoculation to broad bean plants. And then the infected broad bean leaves were used for mechanical inoculation to PI 378159. Three out of six plants infected after inoculation of two viruses recovered from two different individuals, and five out of six were infected after inoculation of a virus culture recovered from one individual. This indicates that those viruses are mutants that overcome the resistance in PI 378159.

Because all the viruses recovered from systemically infected leaves of PI 378159 were resistance-breaking mutants, we next tested whether viruses on particle-bombarded leaves are mutant. Based on the GFP fluorescence phenotype of the particlebombarded leaves of PI 378159, viruses were excised as follows: eight excisions at 5 dai from GFP fluorescence present in multiple cells around infection site (parenchyma cells) and 10 excisions at 8 dai from GFP fluorescence present in the veins (vascular tissue) were used for mechanical inoculation to broad beans plants once

TABLE 1. F1 progenies from the cross between resistant lines with susceptible PI 250438 demonstrated that the resistance is a recessive character

\begin{tabular}{lcccccc}
\hline Resistant lines & PI 162909 & PI 347295 & PI 356986 & PI 378158 & PI 378159 & PI 429853 \\
\hline${\text { Infection of F1 } \text { plants }^{\mathrm{a}}}^{10 / 10}$ & $9 / 9$ & $7 / 7$ & $11 / 11$ & $15 / 15$ & $10 / 10$ \\
\hline
\end{tabular}

${ }^{a}$ Number of infected plants/number of plants tested by green fluorescent protein detection.

TABLE 2. Segregation analysis of resistance in F2 progenies from the cross with PI 250438

\begin{tabular}{lccccc}
\hline Lines & Susceptible & Resistant & Total & $\chi^{2}$ & Goodness of fit, $P=0.05$ \\
\hline PI 347295 & 76 & 24 & 100 & 0.053 & $0.80<P<0.90$ \\
PI 378159 & 74 & 26 & 100 & 0.053 & $0.80<P<0.90$ \\
\hline
\end{tabular}


for propagation and then to PI 378159. The results showed that viruses in all the infection sites, except for two in the parenchyma cells, contained resistance-breaking mutants that infect systemically (Table 4).
Reaction of PI 347295 and PI 378159 inoculated with different isolates of CIYVV and with BYMV. As reported by Masuta et al. (15), the insertion of GFP in ClYVV did not affect the spread of the virus in susceptible plants. However, Germana-

\section{PI 347295}

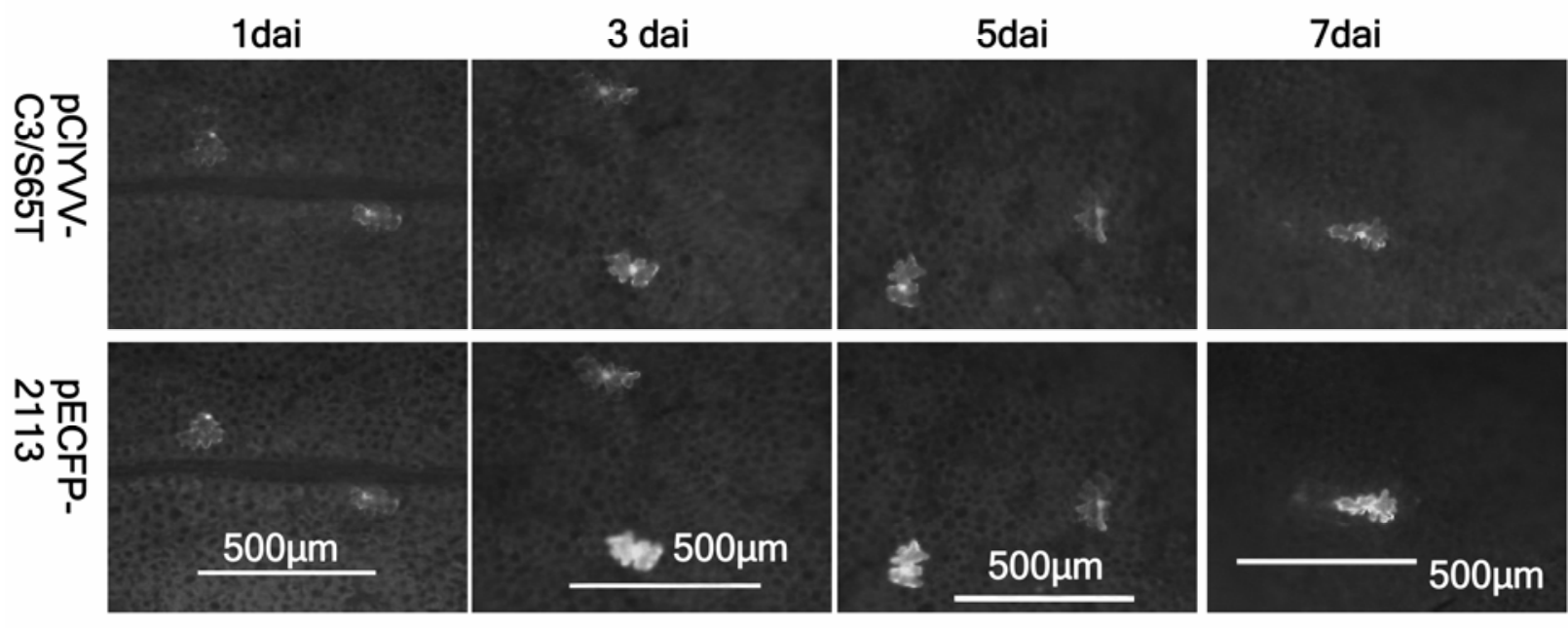

\section{PI 378159}

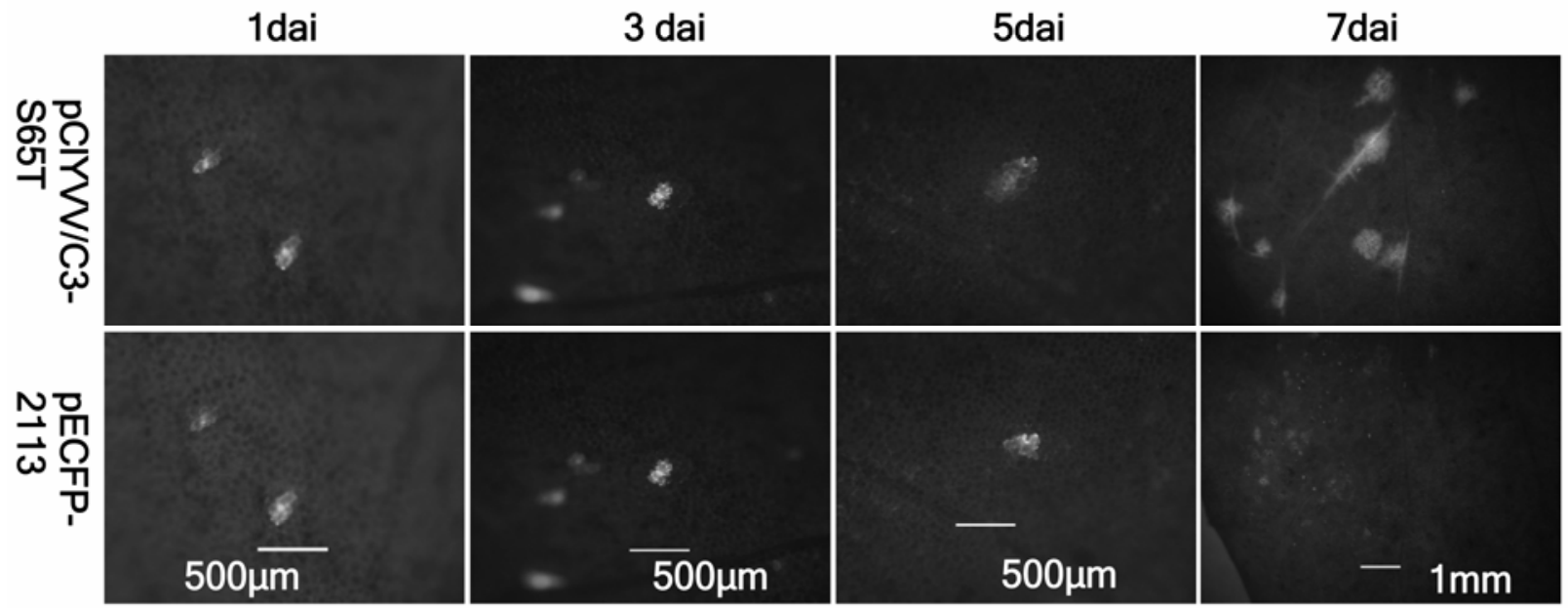

Mametaro

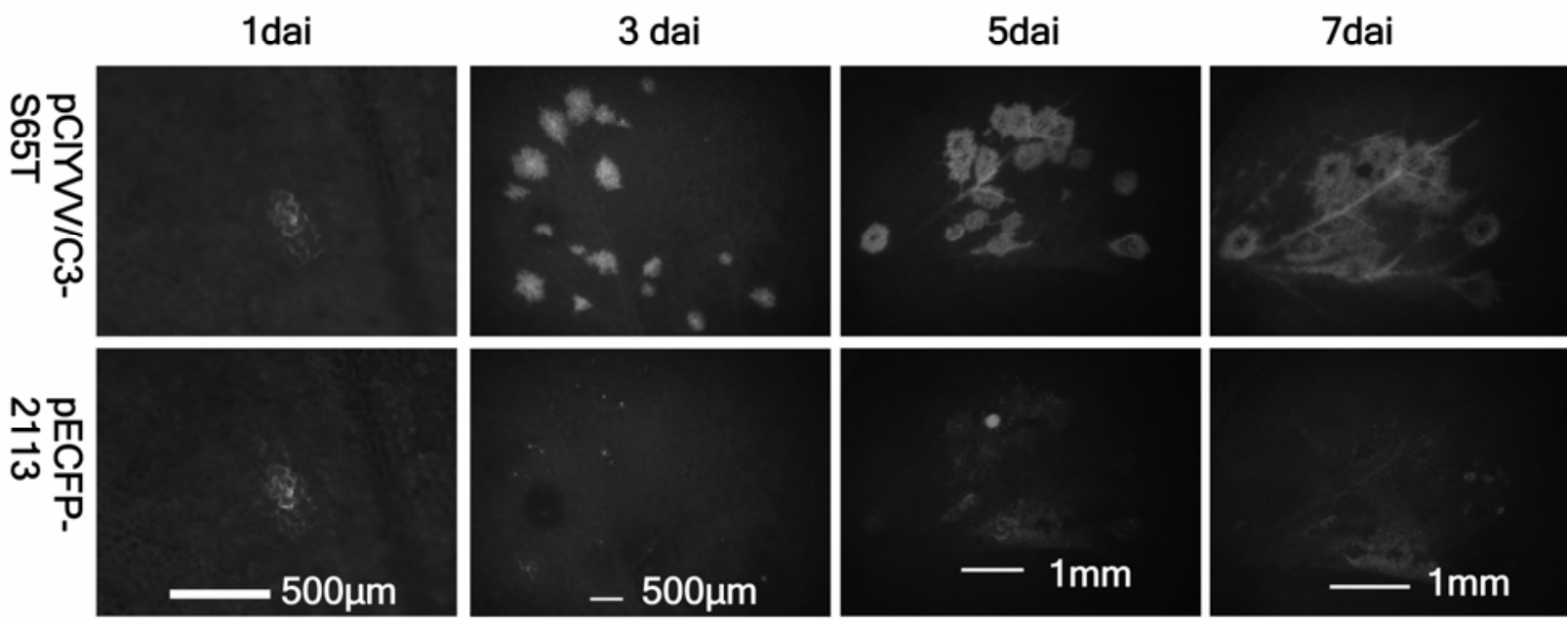

Fig. 1. Particle bombardment on Clover yellow vein virus (ClYVV) resistant pea lines with pCIYVV/C3-S65T. Approximately $1 \mu \mathrm{g}$ of pClYVV/C3-S65T carrying green fluorescent protein (GFP) and pECFP-2113 carrying cyan fluorescent protein (CFP) were coated together in tungsten particles. They were then particle bombarded onto detached leaves of pea lines PI 347295, PI 378159, and Mametaro. An epifluorescence microscope with GFP and CFP filters was used to detect the fluorescence. All plants and detached leaves were maintained in chamber conditions $\left(23^{\circ} \mathrm{C}\right.$ with $18 \mathrm{~h}$ of fluorescent light). 


\section{PI 347295}

\section{3dai}

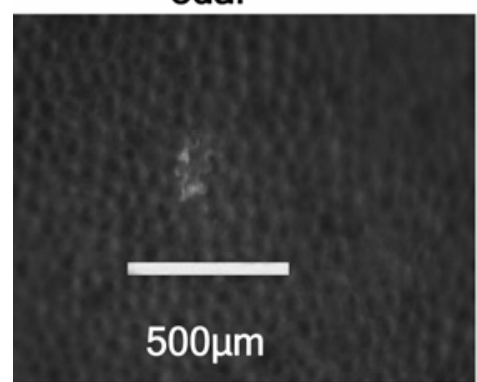

$500 \mu \mathrm{m}$
5 dai

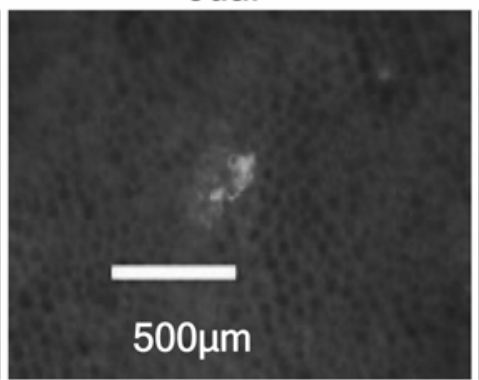

\section{PI 378159}

5dai
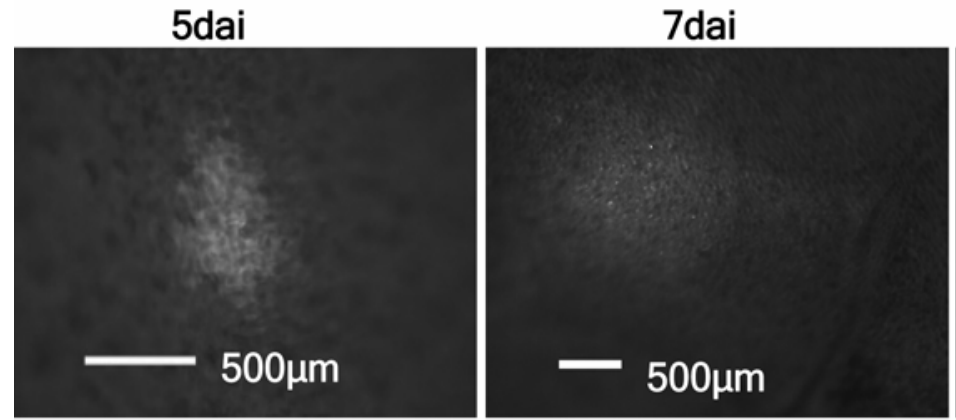

Mametaro

3dai
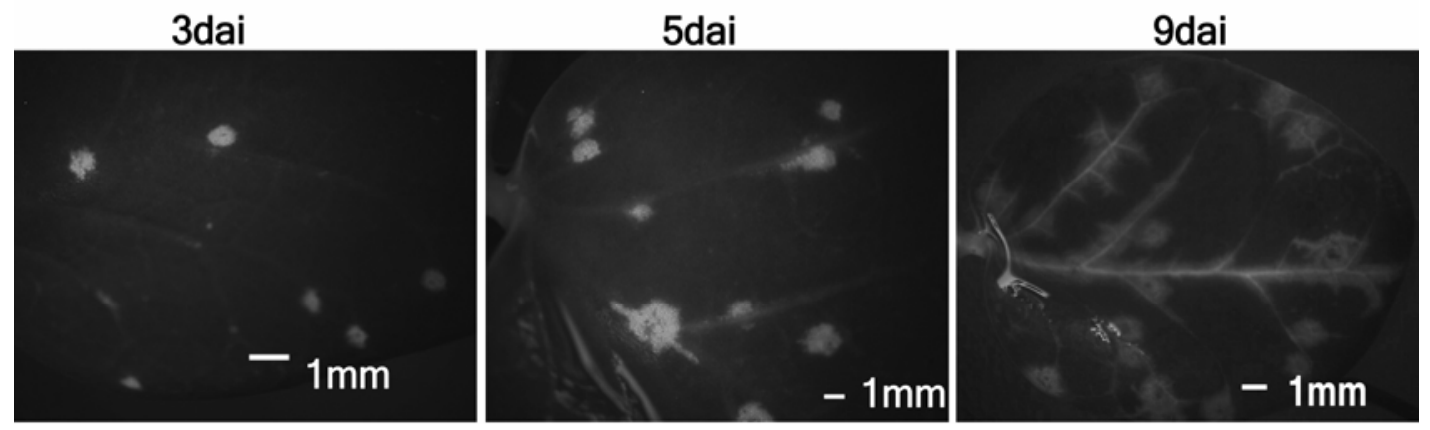

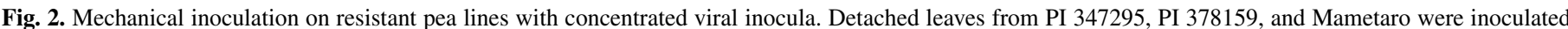

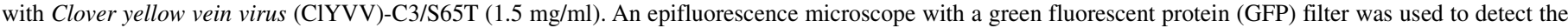
fluorescence. All plants and detached leaves were maintained in chamber conditions $\left(23^{\circ} \mathrm{C}\right.$ with $18 \mathrm{~h}$ of fluorescent light).

TABLE 3. Reaction of PI 378159 and Mametaro inoculated with concentrated viral inocula of Clover yellow vein virus (ClYVV)-C3/S65T

\begin{tabular}{|c|c|c|c|c|}
\hline \multirow[b]{3}{*}{ Inocula } & \multicolumn{2}{|c|}{ PI 378159} & \multicolumn{2}{|c|}{ Mametaro } \\
\hline & Inoculated leaves & Upper leaves & Inoculated leaves & Upper leaves \\
\hline & Number of sites ${ }^{a}$ & Infectivity $^{\mathrm{b}}$ & Number of sites ${ }^{a}$ & Infectivity $^{\mathrm{b}}$ \\
\hline \multicolumn{5}{|l|}{ Concentrated } \\
\hline $1.5 \mathrm{mg} / \mathrm{ml}$ & 0.3 & $2 / 3$ & 18 & $3 / 3$ \\
\hline \multicolumn{5}{|c|}{ 10-fold dilutions of above } \\
\hline $150 \mu \mathrm{g} / \mathrm{ml}$ & - & $1 / 3$ & 12 & $3 / 3$ \\
\hline $15 \mu \mathrm{g} / \mathrm{ml}$ & - & $0 / 3$ & 4 & $3 / 3$ \\
\hline $1.5 \mu \mathrm{g} / \mathrm{ml}$ & - & $0 / 3$ & 1 & $3 / 3$ \\
\hline \multicolumn{5}{|l|}{ Crude extract } \\
\hline $6 \mu \mathrm{g} / \mathrm{ml}$ & - & $0 / 3$ & 8 & $3 / 3$ \\
\hline
\end{tabular}

a Average number of infection sites in six to eight inoculated leaves.

${ }^{\mathrm{b}}$ Number of infected plants/reverse transcription-polymerase chain reaction-assayed plants.

Retana et al. (7) showed that a resistance-breaking strain of Lettuce mosaic virus $E$ tagged with GFP was unable to break resistance. To examine whether tagging of the virus decreased its infectivity, three to five plants were inoculated with ClYVV-
Pst1/CP that contained no GFP insertion. Lines PI 347295 and PI 378159 were resistant and Mametaro was susceptible to ClYVVPstI/CP, showing that the insertion of GFP in ClYVV did not affect the host response (Table 5). 


\begin{tabular}{|c|c|c|c|c|c|c|c|c|c|c|}
\hline & \multicolumn{10}{|c|}{ Individual infection site } \\
\hline & 1 & 2 & 3 & 4 & 5 & 6 & 7 & 8 & 9 & 10 \\
\hline \multicolumn{11}{|l|}{ Parenchyma cells ${ }^{\mathrm{a}}$} \\
\hline Inoculated leaves ${ }^{b}$ & $0 / 3^{c}$ & $0 / 3$ & $1 / 3$ & $3 / 3$ & $1 / 3$ & $1 / 3$ & $1 / 3$ & $3 / 3$ & $\ldots$ & $\ldots$ \\
\hline Systemic leaves $^{\mathrm{d}}$ & $0 / 3$ & $0 / 3$ & $1 / 3$ & $2 / 3$ & $1 / 3$ & $1 / 3$ & $1 / 3$ & $3 / 3$ & $\ldots$ & $\ldots$ \\
\hline \multicolumn{11}{|l|}{ Vascular tissue $^{\mathrm{e}}$} \\
\hline Inoculated leaves & $1 / 3$ & $2 / 3$ & $2 / 3$ & $3 / 3$ & $2 / 3$ & $2 / 3$ & $2 / 3$ & $3 / 3$ & $3 / 3$ & $2 / 3$ \\
\hline Systemic leaves & $1 / 3$ & $2 / 3$ & $2 / 3$ & $3 / 3$ & $2 / 3$ & $2 / 3$ & $2 / 3$ & $3 / 3$ & $3 / 3$ & $2 / 3$ \\
\hline
\end{tabular}

a Viruses recovered from green fluorescent protein (GFP) fluorescence present in multiples cell around infection site.

${ }^{\mathrm{b}}$ GFP detected at 7 days after inoculation (dai).

c Number of infected plants/total.

d GFP detected from 14 to 21 dai and enzyme-linked immunosorbent assay performed at 21 dai.

e Viruses recovered from GFP fluorescence present in the veins.

TABLE 5. Reaction of resistant lines against different virus isolates

\begin{tabular}{lcccc}
\hline & \multicolumn{4}{c}{ Lines } \\
\cline { 2 - 5 } Viruses $^{\mathrm{a}}$ & PI 347295 & PI 378159 & Mametaro & Jolanda $^{\mathrm{b}}$ \\
\hline ClYVV-Br $^{\mathrm{c}}$ & $0 / 5^{\mathrm{d}}$ & $0 / 5$ & $3 / 3$ & $4 / 4$ \\
ClYVV-Pst1-CPe $^{\mathrm{n}}$ & $0 / 5$ & $0 / 5$ & $3 / 3$ & $\ldots$ \\
BYMV-CS $^{\mathrm{f}}$ & $0 / 4$ & $4 / 4$ & $3 / 3$ & $\ldots$ \\
\hline
\end{tabular}

a All viruses were tested using enzyme-linked immunosorbent assay.

${ }^{\mathrm{b}}$ Common bean line used as a control.

c Clover yellow vein virus (ClYVV)-Br is a resistance-breaking strain described by Sato et al. (22).

d Number of infected plants/tested plants.

e The No. 30 isolate with no insertion of green fluorescent protein described by Masuta et al. (15).

${ }^{\mathrm{f}}$ A strain of Bean yellow mosaic virus (BYMV) described by Sato et al. (21).

Sato et al. (22) described a mutant strain of ClYVV (ClYVV$\mathrm{Br}$ ) that was able to overcome the resistant gene desc in common bean cv. Jolanda. However, the strain was unable to overcome resistance in PI 347295 and PI 378159 (Table 5). BYMV is closely related to CIYVV (30) and was once classified as the same virus (11). PI 347295 and PI 378159 were resistant and susceptible to BYMV, respectively (Table 5). The above results indicate that tagged CIYVV is an efficient tool for identifying and characterizing resistance in pea plants.

\section{DISCUSSION}

Since Baulcombe et al. (2) introduced GFP techniques to monitor viral infection in the genome using Potato virus $X$, many papers have described the use of GFP for monitoring viruses. Tagging a virus with GFP is particularly useful in understanding resistant mechanisms, and cell-to-cell and systemic movements of the virus $(3,13,25,26)$. Previously, we successfully used a GFPtagged virus to analyze resistance to CIYVV infection in bean $\mathrm{cv}$. Jolanda (22). Here, direct monitoring of viral replication and movement by GFP fluorescence revealed two different resistance modes in pea. In PI 347295, the virus replicated on a single-cell level, but could not spread to neighboring cells. In PI 378159, the virus spread to surrounding cells, reached the veins, and executed vascular transport (Fig. 1).

Identified recessive resistance mechanisms to potyviruses operate either by inhibiting viral replication, as in the $e t^{a}$ (5), sbml (12), and desc (22) genes, or by blocking the cell-to-cell movement, as in $v a$ (14) and $y^{a}$ (1). For $s b m 2$, the resistance mechanism operates by blocking viral replication or cell-to-cell movement (10). The resistance mechanism of line PI 347295 was similar to the above cases in which recessive resistance operates at a cell-tocell movement step. However, resistance in PI 378159 was not caused by complete inhibition of viral replication or blocking of the cell-to-cell movement, but rather by a slowing of these events.

In the initial screening of pea lines by conventional mechanical inoculation with crude sap, all resistant lines showed no GFP fluorescence, even on inoculated leaves. However, many infection sites were detected on the inoculated leaves of resistant pea lines when infectious cDNA was introduced by a particle bombardment method. Table 4 shows that once CIYVV establishes infection, mutants emerge at a high rate during multiplication of the virus in neighboring cells around the infection site allowing the virus to move systemically. Particularly, all 10 virus cultures recovered from 10 different excisions from vascular tissue were able to move systemically in PI 378159. This agrees with inoculation using concentrated viral inocula (Table 3), in which all viruses that reached the vascular system were resistance-breaking mutants.

Because susceptible pea could be infected with $1.5 \mu \mathrm{g} / \mathrm{ml}$ of the virus, far below the concentration required for infection in PI 378159 , that line is still considered to be resistant to ClYVV. This discrepancy reflected differences in the susceptibility of pea to the two inoculation methods. Introduced plasmids continuously transcribed enough viral RNA to establish infection in PI 378159. Thus, we conclude that ClYVV cannot establish infection by mechanical inoculation on both lines, PI 347295 and PI 378159. However, in PI 347295 when CIYVV establishes infection by particle bombardment or by highly infectious inocula, the resistance operates by not allowing the virus to move cell-to-cell. In contrast, when ClYVV establishes infection in PI 378159, the resistance operates by preventing transportation to the vascular system, but this resistance is very easy to break and mutants appear in the veins that later move systemically to the upper noninoculated leaves.

Provvidenti (16) reported two recessive genes, $c y v$ and $c y v-2$, that are resistant to ClYVV. It is unknown whether these are the same genes as those described here. We are currently determining whether resistance genes present in PI 347295 and PI 378159 are identical to either $c y v$ or $c y v-2$.

\section{ACKNOWLEDGMENTS}

This work was supported in part by a Grant-in-Aid for Scientific Research on Priority Areas and a Grant-in Aid for Scientific Research from the Ministry of Education, Culture, Sports, Science, and Technology of Japan (no. 08680733) to I. Uyeda. We thank C. Coyne for generously supplying the plant lines used in this study.

\section{LITERATURE CITED}

1. Arroyo, R., Soto, M. J., Martines-Zapater, J. M., and Ponz, F. 1996. Impaired cell-to-cell movement of potato virus $\mathrm{Y}$ in pepper plants carrying the $y^{\mathrm{a}}\left(p r 2^{1}\right)$ resistance gene. Mol. Plant-Microbe Interact. 9:314318.

2. Baulcombe, D. C., Chapman, S., and Cruz, S. S. 1995. Jellyfish green fluorescent protein as a reporter for virus infections. Plant J. 7:1045-1053.

3. Cohen, Y., Gisel, A., and Zambryski, P. C. 2000. Cell-to-cell and systemic movement of recombinant green fluorescent protein-tagged Turnip crinkle viruses. Virology 273:258-266.

4. Collmer, C. W., Marston, M. F., Taylor, J. C., and Jahn, M. 2000. The I gene of bean: A dosage-dependent allele conferring extreme resistance, 
hypersensitive resistance, or spreading vascular necrosis in response to the potyvirus Bean common mosaic virus. Mol. Plant-Microbe Interact. 13:1266-1270.

5. Deom, G. M., Murphy, J. F., and Onofre, R. P. 1997. Resistance to Tobacco etch virus in Capsicum annuum: Inhibition of virus RNA accumulation. Mol. Plant-Microbe Interact. 10:917-921.

6. Gal-On, A., Meiri, E., Elman, C., Gray, D. J., and Gaba, V. 1997. Simple hand-held devices for the efficient infection of plants with viral-encoding constructs by particle bombardment. J. Virol. Methods 64:103-110.

7. Germana-Retana, S., Candresse, T., Alias, E., Delbos, R. P., and Le Gall, O. 2000. Effects of green fluorescence protein or $\beta$-glucuronidase tagging on the accumulation and pathogenicity of a resistance-breaking Lettuce mosaic virus isolate in susceptible and resistant lettuce cultivars. Mol. Plant-Microbe Interact. 13:316-324.

8. Gilpin, B. J., McCallum, J. A., Frew, G. M., and Timmerman-Vaughan, G. M. 1997. A linkage map of the pea (Pisum sativum L.) genome containing cloned sequences of known function and expressed sequences tags (ESTs). Theor. Appl. Genet. 95:1289-1299.

9. Hämäläinem, J. H., Kekarainen, T., Gebhardt, C., Watanabe, K. N., and Valkonen, J. P. T. 2000. Recessive and dominant genes interfere with the vascular transport of Potato virus $A$ in diploid potatoes. Mol. PlantMicrobe Interact. 13:402-412.

10. Johansen, I. E., Lund, O. S., Hjulsager, C. K., and Laursen, J. 2001. Recessive resistance in Pisum sativum and potyvirus pathotype resolved in a gene-for-cistron correspondence between host and virus. J. Virol. 75:6609-6614.

11. Jones, R. T., and Diachum, S. 1977. Serologically and biologically distinct bean yellow mosaic virus strains. Phytopathology 67:831-838.

12. Keller, K. E., Johansen, I. E., Martin, R. R., and Hampton, R. O. 1998. Potyvirus genome-linked protein (VPg) determines pea seed-borne mosaic virus pathotype-specific virulence in Pisum sativum. Mol. PlantMicrobe Interact. 11:124-130.

13. Krishnamurthy, K., Mitra, R., Payton, M. E., and Verchot-Lubicz, J. 2002. Cell-to-cell movement of the PVX $12 \mathrm{~K}, 8 \mathrm{~K}$, or coat proteins may depend on the host, leaf developmental stage, and the PVX $25 \mathrm{~K}$ protein. Virology 300:269-281.

14. Masuta, C., Nishimura, M., Morishita, H., and Hataya, T. 1999. A single amino acid change in viral genome-associated protein of Potato virus $Y$ correlates with resistance breaking in 'Virgin A Mutant' tobacco. Phytopathology 89:118-123.

15. Masuta, C., Yamana, T., Takahashi, Y., Uyeda, I., Sato, M., Ueda, S., and Matsumura, T. 2000. Development of Clover yellow vein virus as an efficient, stable gene-expression system for legumes species. Plant J. 23:539-546.

16. Provvidenti, R. 1987. Inheritance of resistance to Clover yellow vein virus in Pisum sativum. J. Hered. 78:126-128.
17. Provvidenti, R. 1991. Inheritance of resistance to the NL-8 strain of Bean common mosaic virus in Pisum sativum. J. Hered. 82:353-355.

18. Provvidenti, R., and Hampton, R. O. 1993. Inheritance of resistance to White lupin mosaic virus in common pea. Hortic. Sci. 28:836-837.

19. Provvidenti, R., and Niblett, C. L. 1994. Inheritance of resistance to a strain of Passionfruit woodiness virus in pea (Pisum sativum). Hortic. Sci. 29:901-902.

20. Ravelo, G., Kagaya, U., Inukai, T., Sato, M., and Uyeda, I. 2007. Genetic analysis of lethal tip necrosis induced by clover yellow vein virus infection in pea. J. Gen. Plant Pathol. 73:59-65.

21. Sato A., Ohshima, K., Sano, T., Uyeda, I., and Shikata, E. 1987. Comparison of direct and indirect ELISA among different isolates of BYMV. J. Fac. Agric. Hokkaido Univ. 63:277-286.

22. Sato, M., Masuta, C., and Uyeda, I. 2003. Natural resistance to Clover yellow vein virus in beans controlled by a single recessive locus. Mol. Plant-Microbe Interact. 16:994-1002.

23. Schroeder, W. T., and Provvidenti, R. 1971. A common gene for resistance to Bean yellow mosaic virus and Watermelon mosaic virus 2 in Pisum sativum. Phytopathology 61:846-848.

24. Solomon-Blackburn, R. M., and Barker, H. 2001. A review of host majorgene resistance to potato viruses $\mathrm{X}, \mathrm{Y}, \mathrm{A}$ and $\mathrm{V}$ in potato: Genes, genetics and mapped locations. Heredity 86:8-16.

25. Spillane, C., Verchot, J., Kavanagh, T. A., and Baulcombe, D. C. 1997. Concurrent suppression of virus replication and rescue of movementdefective virus in transgenic plants expressing the coat protein of Potato virus $X$. Virology 236:76-84.

26. Sudarshana, M. R., Wang, H. L., Lucas, W. J., and Gilbertson, R. L. 1998. Dynamics of Bean dwarf mosaic gemini virus cell-to-cell and longdistance movement in Phaseolus vulgaris revealed using the green fluorescence protein. Mol. Plant-Microbe Interact. 11:277-291.

27. Takahashi, Y., Takahashi, T., and Uyeda, I. 1997. A cDNA clone of Clover yellow vein potyvirus genome is highly infectious. Virus Genes 14:235243.

28. Uyeda, I. 1992. Bean yellow mosaic virus subgroup; Search for the group specific sequences in the $3^{\prime}$ terminal region of the genome. Arch. Virol. 5(suppl.):377-385.

29. Uyeda, I., Kojima, M., and Murayama, D. 1975. Purification and serology of Bean yellow mosaic virus. Ann. Phytopathol. Soc. Jpn. 41:192-203.

30. Uyeda, I., Takahashi, T., and Shikata, E. 1991. Relatedness of the nucleotide sequence of the 3'-terminal region of Clover yellow vein potyvirus RNA to Bean yellow mosaic potyvirus RNA. Intervirology 32:234-245

31. Walsh, J. A., Sharpe, A. G., Jenner, C. E., and Lydiate, D. J. 1999. Characterization of resistance to Turnip mosaic virus in oilseed rape (Brassica napus) and genetic mapping of TuRBO1. Theor. Appl. Genet. 99:1149-1154. 